We acknowledge gratefully a succession of grants from the Rockefeller Foundation which have made this work possible, and the hospitality of Rothamsted Experimental Station, which has allowed it to be continued after 1940 .

${ }^{1} J$. Genet., 33, 25 (1936).

${ }^{2} J$. Genet., 38, 37 (1939).

3. Genet., 39, 47 (1939).

" "Genetics".

${ }^{5}$ Drosophila Information Service, 15, 39 (1941).

' $Z$. Zellf. u. mikro. Anat., 26 (1937).

" "The New Systematies", 185 (Oxford: Clarendon Press, 1940).

${ }^{8}$ Jap. J. Genet., 12 (1936).

.J. Genet., 34, 415 (1937)

10 Genetica, 20, 458 (1938).

${ }^{11}$ Carnegie Institution of Washington Pub., 399 (1929).

${ }^{12}$ Carnegie Institution of Washington Pub., 552 (1944).

13 Nature, 149, 527 (1942).

14 J. Genet., 45, 206 (1943).

${ }^{15}$ Proc. Roy. Soc., B, 130, 185 (1941).

\section{HEALTH EDUCATION IN YOUTH SERVICE*}

$\mathrm{T}$ HE Central Council for Health Education, which is recognized, by the Government as one of its agencies for health education, has thought it timely to outline the part that it considers health education should play in the youth service of the future.

The general standard of health in the community at present falls so far short of possibilities that there is obviously much room for improvement ; and one of the ways in which it can be improved is through health education. Clearly, education alone will not be sufficient-there is needed also an improvement in community conditions (particularly in regard to housing and nutrition). But it is only through education that people can be encouraged to make the best use of conditions as they exist and be made aware of the possibilities of improving them.

Ideally, health education should be a way of living and something that is almost insensibly absorbed in the home, the school, the youth organization and the work place, rather than a formal subject taught in set sessions at set times. It has, however, at least three important aspects--the imparting of knowledge, the inculcation of habits and the encouragement of attitudes. Knowledge will not of itself lead to better health; but it provides the intellectual background to habits already acquired and helps in the development of healthy attitudes. Many of the most important health habits must be inculcated long before the child is capable of assimilating the knowledge which justifies them; but their practice should be reinforced by theoretical understanding as soon as possible. Attitudes are influenced by home environment from the very earliest days, and in particular by the way in which habit-training is carried out, but they also require intellectual understanding for their fullest development. These three aspects of health education are thus closely inter-related.

Knowledge important in health education includes an understanding of the structure and functioning of the body and of the relationship between physical and mental health. Important also is an understanding of how the spread of disease occurs and how it can be prevented or reduced; a grasp of the social factors influencing the health and well-being of the community; and a knowledge of the personal and

- Memorandum by the Central Council for Health Education. social measures necessary to enhance health and build up resistance to disease.

The bodily habits relevant to health education include those consisting essentially of the disciplining of natural functions (for example, eating and voiding) and those others (for example, personal cleanliness) which are essentially, habits of civilization. Equally important are the habits of the mind and of behaviour in relation to society.

Among the important attitudes are those of nor$\mathrm{m}$ ulity towards the body and its functions, deviating neither towards prudish avoidance nor towards prurient curiosity; of regarding health not as a mere absence of disease, but rather as a positive state of joyous well-being ; and of feeling a sense of responsibility for the state of personal, family and community health.

Since young people do not enter within the scope of the youth service at the age of fourteen without having been influenced very considerably by their earlier training, any consideration of the type of health education appropriate to the period of adolescence is dependent upon the making of certain assumptions about what will have been achieved before this period is reached. It seems reasonable to assume that by the time children reach the age of fourteen, they will have received in home, school and juvenile organizations, health education along the three lines of imparting of knowledge, inculcation of habits and encouragement of attitudes indicated above, up to levels appropriate to their stage of development. The definition of these levels is in the main a matter for parents and teachers, and those responsible for the youth service will need to continue to build from the levels already reached.

\section{Health Education in Youth Service}

The special functions of health education in adolescence would appear to be the reinforcement and widening of earlier education, especially in those directions most affected by the maturing ideals, emotions, experiences and activities of this period. With the statutory raising of the school-leaving age, some of this education will be given in the last year or two at school, and with the establishment of young people's colleges, some will be given during part-time compulsory education. The extra year or two of compulsory education would be most usefully employed in giving systematic instruction in those aspects of health education for which the adolescent is now sufficiently mature-in intellectual and emotional development and in social experience and awareness. For many young people, this will be the last opportunity for systematic instruetion, and full advantage should be taken of it.

A great deal, however, will still remain as the special function of voluntary instructional classes and youth organizations.

The whole spirit of health education in youth service should be such as to encourage the development in adolescents of an appreciation of the possibilities of reaching a high standard of personal and community health and the growth of a sense of individual responsibility for reaching this standard. Certainly importance should be attached to the measures which are required from the State, the local authorities, ete.; but it needs emphasizing that increasing social provision should be accompanied by greater individual effort.

Adolescents particularly need help in meeting the peculiar problems of the period through which they 
are passing : in physical problems such as the coping with the bodily changes of adolescence; emotional problems such as those arising from the development of sexual interests and urges; and social problems such as those of the relations between the young people and their parents, between young men and young women, and between the individual and society.

The age-range covered, by youth service is one in which young people are very interested in the development of physical fitness, strength, agility and grace ; and any plans for health education should take full advantage of this interest. The keen desire to make oneself attractive to other people provides a very valuable opportunity for education in the care of the body generally and pərhaps particularly in the attainment of grace and poise and in the care of the hair and complexion.

The period of adolescence is also one in which it is essential to give some training for approaching maturity. Examples of such training are marriage preparation, parentcraft, home economics, and instruction in the measures needed for the maintenance in full health of the individual, the family and the community.

It is clear that in most youth organizations very little will be possible in the way of systematic courses of instruction. Young people in their leisure hours wish for recreation, and lectures should be arranged mainly in response to demands made by the members themselves. The skilful teacher will be able to stimulate such demands-often as a result of informal discussions which make clear the need for further information on specific topics-and lectures which have been requested by the members are likely to be given much more attention than would have been the case had they been forced on the members by the leader.

But while it is true that the atmosphere and practice of the educational system will be a vital part of health education throughout, this is pre-eminently true of the youth organizations. The whole routine of the club-activities, toilet arrangements, concern for the cleanliness of premises and equipment, insistence that habits acquired in the organization are for everyday use and not 'for club night only', personal relationships between leaders and members and between one member and another-is of the utmost importance. Thus the encouragement of camping, rambling, youth hostels, etc., as well as the more formal type of physical recreation, is an essential part of health education.

The extent to which health education will be carried out in youth organizations will depend largely upon the degree to which the leaders are themselves educated, able to colour the whole life of their organization, and able and ready to stimulate and respond to demands for information. In addition, therefore, to those qualities of personality which are essential to any successful youth work, all leaders should be alive to the need for and the possibilities of health education, should themselves have a positive attitude to health and should have that necessary minimum of basic factual knowledge which will enable them to plan their programmes in the best way.

Moreover, each club or group of clubs should have at least one leader specially qualified in health education. This person might in many cases be the physical recreation instructor, in other cases the instructor in first aid and home nursing or allied subjects.
Ideally, too, each club would have a medical adviser-who would be available to advise the youth leaders and the young people upon matters within his province. It must be recognized, however, that this ideal will not be attained for a long time ahead, and it is therefore all the more important that meanwhile there should be a corps of fairly highly trained youth leaders (each of whom might serve a group of clubs) who, while naturally not attempting to carry out the work of a medical practitioner, would nevertheless be able to give the organizations covered by them skilled help and advice on the principles of healthy living. The Central Council for Health Education is able to give local authorities help in training youth leaders to carry out this work.

No amount of training will make good leaders out of poor material ; but native abilities and aptitudes may be reinforced by courses of instruction. In the organization of such courses the Central Council for Health Education again can give considerable help, and indeed, regards the training of youth leaders as one of its most important tasks. It has already held many such courses and is developing co-operation with the Central Council of Physical Recreation so that theory and practice may march together.

In this connexion, it is worth considering the institution of a certificate in health education along lines somewhat similar to that in physical recreation, awarded at present by the Central Council of Physical Recreation. Youth leaders, like other students, are the more likely to give serious study to a matter when they are working for a test, and have a natural desire for some documentary evidence of the standard they have attained. The Central Council for Health Education hopes to discuss with the Board of Education and its Youth Advisory Council the desirability of such a certificate and the terms upon which it might be awarded to persons judged suitable from other points of view.

While it is true that the best youth leaders can do excellent work even in a very poor environment, it is equally true that a general high standard of achievement depends upon the availability of adequate accommodation and equipment. Club premises which, with proper cloakroom, lavatory and toilet accommodation, will reinforce, not contradict, health teaching; physical recreation apparatus, playing fields, camping sites, swimming pool, youth hostels-these are the basic material requirements. There is also particular need for a permanent residential school, with attached model club, in which, throughout the year, youth leaders from all parts of the country may gather for training and refresher courses, of which the theory and practice of health education should form an important part.

\section{THE PHILOSOPHY OF RESEARCH}

7 HE American Philosophical Society arranged a 1 symposium on the "Organisation, Direction and Support of Research" for its autumn meeting, held during November 19-20, 1943, and the papers presented have now been published (Proc. Amer. Phil. Soc., 87, No. 4, January 29, 1944). Together they constitute a notable contribution to the philosophy of research, dealing on the whole with strategy rather than with tactics, and though concerned primarily with American conditions, they are highly relevant to the present discussions in Great Britain on the 